\title{
CULTURAL DETERMINANTS OF CORPORATE GOVERNANCE: A MULTI-COUNTRY STUDY
}

Pedro Paulo Melo Arantes ${ }^{1}$, Fernanda Maciel Peixoto, Luciana Carvalho, Fernanda Francielle de Oliveira Malaquias Universidade Federal de Uberlândia - UFU, Uberlânica, MG (Brasil)

\section{ARTICLE DETAILS}

\section{Article history:}

Received: 5 November 2019

Accepted: 3 March 2020

Available online May: 01 th 2020

Double Blind Review System

Scientific Editor

Ilan Avrichir

\section{Key words}

Corporate Governance

Earnings Management

Culture

\begin{abstract}
Purpose: The purpose of this study was to investigate if the culture of countries influences earnings management practices. Earnings management (EM) was chosen as a Corporate Governance mechanism.

Methodology: We selected the Earnings Management proxies from Leuz et al. (2003). We adopted Hosftede's cultural dimensions: power distance, individualism, uncertainty avoidance and long term orientation. The sample comprised companies listed in 2016 in the stock markets of Brazil, Argentina, Mexico, Chile, Colombia, Peru, and the United States. This work involved regression analysis to associate the dimensions of culture with the practice of EM of the firms.

Findings: The results showed a positive relationship between EM and power distance and between EM and uncertainty avoidance. On the other hand, the results showed a negative relationship between EM and individualism and between EM and long term orientation. Overall, our results suggest that culture influences firms' earnings management.

Originality/value: Finance literature has had difficulty in assessing which variables can affect the development of CG in companies and its peculiarities in each country. It is also difficult to find country-level variables that are common to all countries. This paper breaks new ground by developing culture indicators of the countries and aggregating legal and firm-level variables to these indicators to advance the understanding of CG in the firms and nations.

Theoretical and methodological contributions: studying culture at a multi-country level is important to improve the understanding of common aspects and the countries' particularities that may affect the relationship between corporate governance and performance around the world.
\end{abstract}

\section{Introduction}

This paper investigates how a country-level factor can influence an internal aspect of the organization. More specifically, this paper tests whether the culture of the countries could impact the practice of Earnings Management of the organizations of such countries. It seeks to understand the role of culture as a potential determinant of corporate governance (CG), which is an aspect that is still little explored.

In the last decades, several studies have analyzed the determinants of $C G$ at the country level and at the firm level. A lot of studies (Hillier et al., 2010; Klapper \& Love, 2004; Kumar et al., 2017; Zattoni, 2013) have investigated countries' perspectives and how their differences explain the way CG is adopted in companies.

Culture is one of the aspects that differentiates one country from another. In recent years, some studies (Griffin et al., 2014, 2017; Volonté, 2015) have investigated variables that could explain the variations in CG among countries, considering cultural differences of the countries. However, finance literature has still faced difficulties to assess which variables affect the development of CG in firms. Black et al. (2014) discussed the difficulty of finding country-level variables common to all countries, analysing the BRIKTs (Brazil, Russia, India, Korea and Turkey). Black et al. (2014) pointed out how specific country-level variables can predict firm value, but they highlighted how difficult it is to obtain elements common to all.

Hofstede proposed a model that assigns values to cultural dimensions, which enabled the development of several quantitative studies involving countries' cultural aspects. Within this scenario, the main purpose of this paper is to analyze whether culture influences EM. Licht et al. (2005) found that the 
cultural dimensions and the legal system, especially in the CG context, are related. They inferred that the culture of a nation may influence the laws and the governance itself. Therefore, and according to Griffin et al. $(2014 ;$ 2017), to introduce the culture of the country as a determining CG factor may be the differential to better adjust the existing governance models and to understand the behavior of financial markets of each country.

Based on this perspective, this paper studies CG using a country-level approach, considering also the culture of a country and the legal factors that can influence governance levels, in particular, EM. Therefore, this study advances the literature since it incorporates the culture of a country as a potential determinant of CG. This study also contributes with information related to country-level variables that affect earnings management and with the consideration of new alternatives to explore and better understand the subject. The proxy used to represent CG is earnings management.

In Brazil, we did not found any other study that addressed countries' culture and its effect on the levels of corporate governance of those countries. Considering the international studies on this topic, we found the following: Griffin et al. (2014), and Griffin et al. (2017). However, the last ones use an index of governance quality of the countries. We used a measure based on earnings management to represent a proxy for corporate governance.

According to the literature, corporate governance's concept is multidimensional, involving mechanisms related to the board of directors; ownership structure and control; minority shareholders' protection; managers' compensation and information transparency. This study focuses on the latter one, as it represents communication with investors. We measured transparency through the model of Leuz et al. (2003), which proposes to measure the quality of the published information through measures of financial data smoothing.

We employed a multivariate regression with firms located in the United States, Mexico, Brazil, Chile, Colombia, Peru, and Argentina to check the relationship between cultural and legal dimensions and EM practices which represents CG in this research. Regarding culture, this is a cross-section study of 2016, since it was the last year with data available at the time of data collection. Culture does not change unless events like wars, national plagues, or intense weather disasters happen; therefore, we used cultural data from previous studies and updated in 2010 (Hofstede, 2001).

Regarding the results found in this study, it is possible to note that in more individualistic societies there is a lower level of EM. Furthermore, it was observed that in societies where individuals more easily accept the inequality in the distribution of power, there is a higher level of EM. It was also noted that in societies more oriented to the future, to economies and to persistence (long term orientation) there is less incidence of EM practices and that in societies with a high level of risk aversion, there are more practices of EM. In other words, it can be inferred from this study that the general culture of the countries investigated influences the level of EM of the firms of such countries.

This research can offer great contributions to scholars, practitioners, and regulators. Readers would certainly appreciate these contributions, since earnings management has become a relevant topic in many studies (Bao \& Lewellyn, 2017; Callen et al., 2011; Correia et al., 2017; Desender et al., 2011; Zhang et al., 2013). Moreover, studying culture at a multi-country level is important to improve the understanding of common aspects and the countries' particularities that may affect the relationship between corporate governance and performance around the world (Griffin et al., 2017; Han et al., 2010; Stahl et al., 2017; Volonté, 2015).

\section{Theoretical framework}

\subsection{Corporate Governance and Earnings Management}

Corporate Governance (CG) represents an essential group of mechanisms between companies and external investors, since it mitigates information asymmetry and agency conflicts. Considering the relevance of good practices related to CG, many studies addressed this topic in the past decades. There is an agreement, for example, that firm-level variables are related to CG. However, studies as those by La Porta et al. (1998), Licht et al. (2005), and Doidge et al. (2007) showed other variables, besides the firm-level ones, that affect how CG is defined in companies, demonstrating that the legal and economic aspect of a country influences governance practices.

To minimize the impacts of agency costs pointed out by Jensen and Meckling (1976), CG outstands in 
the stock market. The stock market, besides the good practice disseminated, fulfills the role of establishing rules to protect the investors and to align their interests within the organization (IBGC, 2015).

As the investor is so important, several countries have drawn up manuals of good practice to guarantee the rights of those interested in investing in their markets and, therefore, enlarging it and attracting foreign investment to these markets. Such concern is seen in various codes of good CG practices of the countries' stock markets. United Kingdom, Canada, Ireland, the United States, New Zealand, and Australia are examples of countries with strong CG codes, as seen in the Governance Metrics International (GMI) data in 2010 and also in the CG manuals of each country.

In Brazil, B3 and the Brazilian Institute of CG (IBGC) highlight the transparency (measured in this study by the EM) as an important principle that companies should follow. According to IBGC, transparency can be defined as the need to provide accurate and timely information to interested parties, not only those required by law, but also including factors beyond the financial performance, such as managerial strategies and actions, to increase organizations' value.

In this study, the Earnins Management (EM) measure proposed by Leuz et al. (2003) was used as a proxy for the transparency of the information disclosed by companies. Leuz et al. (2003) analyze the association between a country's institutional framework to protect the rights of investors and the level to which firms in that region engage in EM. It is known that legal protection limits the expropriation of minority shareholders by the controlling shareholders, reducing the incentives for the practice of EM (Leuz et al., 2003).

Schipper (1989) defined EM as an intentional intervention in the disclosed financial statements, with the purpose of obtaining some particular gain. A decade later, Healy and Wahlen (1999) attributed EM to a broader concept, referring to it as the discretionary act of managers to use judgment in the financial statements in order to induce stakeholders to errors regarding the performance underlying the company, or to influence contractual decisions that depend on accounting numbers.

The definition of EM involves not only the accounting choices that may be reflected in the results disclosed in the financial reports; such definition also involves operational decisions, such as investment decisions, changes in the volume of production and other expenses that directly impact the cash flow of the organizations.

It should be noted that the concept of EM is not related to fraudulent accounting, since the former finds support in the discretion allowed by the accounting standards themselves, while the latter violates the legal standards (Martinez, 2013). Studies conducted in Brazil on EM point to its negative relationship with the quality of CG of Brazilian companies (Barros et al., 2013; Holanda, 2012; Torres et al., 2010).

After presenting the concept of EM and its relation to $C G$ and the transparency of the disclosed information, the next sub-section presents how the dimensions of culture are defined in this study.

\subsection{Culture and its dimensions}

The word "culture" has several meanings based on the field of knowledge and the time period. However, we use a contemporary concept, based in the definition of one of the most cited researchers of "culture": Geert Hofstede. He defines culture as a "the collective programming of the mind distinguishing the members of one group or category of people from others" (Hofstede Insights').

To measure the country's culture, Hofstede (1980) proposed a model with four basic dimensions, which are: Power distance, Uncertainty Avoidance, Individualism versus Collectivism, and Masculinity. Later, Hofstede (2001) added Long-term Orientation as a fifth dimension. In 2017, the union of Itim International and The Hofstede Centre gave rise to Hofstede Insights', which discriminates a sixth dimension, Indulgence. In this study the cultural dimensions that are most likely to be associated with EM were selected based on the works of Callen et al. (2011), Desender et al. (2011), Doupnik (2008) and Nabar and Boolert-U-Thai (2007).

Many studies use Hofstede's cultural dimensions. Ferreira et al. (2014) did a bibliometric study involving the top finance journals (based on impact factor), considering an analysis of 30 years. They found that Hofstede's original study has almost 8 thousand quotations since its publication. Moreover, based on the 10,947 studies of the sample, 655 cited the original study of Hofstede. They conclude that Hofstede's cultural dimensions are largely used in the context of social sciences. 
According to Hofstede (2001) and Hofstede Insights, the dimensions considered in this study consist of:

- Power Distance It is a degree of how much less powerful members of a civilization accept and expect unequal distribution of power in a society.

- Uncertainty Avoidance: It is the degree of risk perceived by the members of a culture in uncertain situations, that is, it reflects the feeling of discomfort or insecurity with risks, chaos, and unstructured situations.

- Individualism versus Collectivism: It is the extent to which people feel they have to take care of themselves, of their families or organizations they belong to. This dimension indicates whether a society is a social network without relationship among individuals, in which individuals are supposed to take care only of themselves, or this society offers a tightly-knit social framework.

- Long-term Orientation versus Short-term Normative Orientation: Long term involves future-oriented values, as savings and persistence; short term involves the values directed towards the past and the present, regarding tradition and compliance with social obligations.

Hofstede quantifies a value for each dimension, but he also says that such measures are relative and only intended for comparisons, which means that they can promote studies that incorporate culture in their analysis by comparing several countries. Hofstede's cultural dimensions are more widely known; however, other equally valid models can be found, as Schwartz, Trompenaars and Globe Project (Ferreira et al., 2014).

According to Kirkman et al. (2006), the cultural classification of Hofstede represents the most influential national culture framework in business literature. Soares et al. (2007) point that Hofstede's cultural framework remains one of the easiest ways to integrate the concept of culture into academic research in term of time required to collect information, costs and availability of data. However, Khlif (2016) argues that several criticisms have been addressed to Hofstede's approach. Minkov (2017) points that Hofstede's model of national culture has enjoyed enormous popularity but rests partly on faith. He proposes a test of the model's coherence and utility, analyzing 56 countries. He found many limitations in the model.

According to Khlif (2016), five critics were addressed to Hofstede's cultural dimensions that relate to (i) outdated data, (ii) assumptions of ethnic homogeneity in one country, (iii) the connection of cultural dimensions with socio-economic data, (iv) IBM data is not representative for the world and ( $v$ ) the inapplicability of the five dimensions to all countries. For example, we know that the survey conducted among IBM employees does not cover all countries. For instance, several countries are not yet included (e.g. Bolivia, Cuba, Tunisia). In addition, for some countries there has been a small number of employees surveyed compared to other and in this may introduce a bias into homogeneity of the sample.

The next sub-section reports the survey of studies that correlate cultural dimensions of countries and Earnings Management.

\subsection{Studies that associate culture and Earnings Management}

There are several studies in the international literature investigating the relationship between culture and earnings management (EM). Guan et al. (2005), for example, analyzed the Hofstede's dimensions in five Asia-Pacific countries. Han et al. (2010) investigated the same dimensions such as individualism and uncertainty avoidance in 32 countries, while Zhang et al. (2013) chose to study Hoftede's Individualism-versus-Collectivism dimensions in 41 countries. Callen et al. (2011) added the religion variable to test the relation between culture and EM. Desender et al. (2011) studied individualism and egalitarianism on EM. Astami et al. (2017) focused on accounting accruals, and Paredes and Wheatley (2017) investigated the impact of economic growth (emerging markets), country, and culture on real EM.

One of the pioneering studies investigating culture versus earnings management is Guan et al. (2005). That study analyzed five Asia-Pacific countries (Australia, Japan, Hong Kong, Malaysia and Singapore), seeking to explore the impact of cultural differences at the country level on earnings management. To that end, the authors elaborated regression models using data from 1987 to 1995 in a pooled analysis. They found that there is a relationship between earnings management (EM) and Hoftede's traditional dimensions, with the individualism dimension showing a positive 
relationship with EM, while uncertainty avoidance and long-term orientation showed a negative relationship.

Similarly, Han et al. (2010) investigated how a system of cultural values can influence EM, using data at the company level from 32 countries in the period from 1992 to 2003. Their main findings showed that individualism is positively related with earnings management, while the opposite is true for uncertainty avoidance, confirming the hypothesis that national culture and institutional structure are important factors for EM. In addition to culture, the authors studied the legal environment and its influence on EM, and realized that culture and institutional environment are conditional on each other.

Desender et al. (2011) study the effect of individualism (defined as the degree to which individuals are integrated into groups) and egalitarianism (defined as a society's cultural orientation with respect to intolerance for abuses of market and political power) on earnings management. Their results show that countries scoring high on individualism tend to have lower levels of earnings management. In addition, this study found that egalitarianism is negatively related to earnings management. Their findings contradict the study by Han et al. (2010). Desender et al. (2011) consider that EM measures can contribute to a better understanding of the cultural dimensions driving managers'distortionary actions on the information they provide.

In order to examine the current state of studies on EM and Culture, Callen al. (2011) used more recent data than the studies mentioned previously and added the religion variable, focusing on testing the effect of culture and religion on EM. They used the EM proxy elaborated by Leuz et al. (2003) and worked with data from 31 countries. Their results confirmed the findings of Desender et al. (2011) and showed that legal variables tend to lose significance when culture is introduced to the model. However, the relationship between Religion and EM was not significant during the tests performed.

Another study which sought to explore the effect of culture on the disclosure of financial earnings was Zhang et al. (2013). The authors chose Hoftede's Individualism-versus-Collectivism dimension due to its conciseness and empirical testing, and because it is related to moral judgment factors regarding social participants. They tested earnings management as a dependent variable. Their findings indicate that the culture in the 41 countries and regions studied had an influence on EM; it was positively associated with the level of Collectivism and negatively associated with investor protection.

Similarly, Astami et al. (2017) sought to investigate the influence of culture and audit quality on the managers' decisions regarding accounting accruals. They analyzed companies experiencing excessive free cash flow, because these companies present more agency conflicts. To reach their goal, the authors studied 6,554 companies listed in Asia-Pacific countries in the period from 2005 to 2010, performing an OLS regression. Their findings indicated that higher uncertainty avoidance leads managers to use more conservative accounting techniques to disclose profits, which reduces the level of earnings management of companies.

Khlif (2016) studies the use of Hofstede's cultural dimensions in accounting research over the period 1995-2015. He found a number of 35 published studies that combine culture and accounting. His work reveals that individualism is positively related to corporate reporting policy, while high levels of masculinity are associated with low disclosure and aggressive accounting manipulations.

In a scenario of economic globalization and harmonization of accounting practices, Paredes and Wheatley (2017) applied hierarchical linear modeling to investigate the impact of economic growth (emerging markets), country, and culture on real earnings management in a sample of companies from 31 countries. They used the Hofstede model to measure cultural dimensions. The findings of their study confirmed the connection between culture and EM, highlighting a negative association of EM with individualism, masculinity, and uncertainty avoidance, but a positive association with power distance.

Based on this literature review and arguments, we present the following hypothesis:

$\mathrm{H} 1$ - Earnings management is positively related to the degree of Power Distance.

$\mathrm{H} 2$ - Earnings management is negatively related to the degree of individualism.

H3 - Earnings management is positively related to the degree of uncertainty avoidance.

$\mathrm{H} 4$ - Earnings management is negatively related to the degree of long term orientation. 


\section{Methodology}

\subsection{Sample and Data Sources}

The sample of this study is comprised of companies with stocks or depositary receipts traded in 2016 in the stock markets of Brazil, Argentina, Mexico, Chile, Colombia, Peru, and the United States of America. Using the Economatica database, we identified the home country of each company in the sample. Those countries with less than 10 companies were excluded of the final sample of this study. Companies from countries without information of cultural dimensions were also excluded of the sample. Moreover, financial companies, investment funds, companies without information of assets, liabilities and revenues of 2015 and 2016 were eliminated of the sample. The final sample contains 3,687 companies of the following countries: Argentina, Brazil, Canada, Chile, China, Colombia, France, Greece, Mexico, Peru, Taiwan, the Netherlands, the United Kingdom and the United States of America. It is important to note that the sample of this study does not necessarily includes a representative sample of each of these 14 countries, since we included in the sample only those companies with depositary receipts traded at the Stock Exchanges of Brazil, Argentina, Mexico, Chile, Colombia, Peru, and the United States of America.

We obtained the firm-level data from the Economatica database. Freedom House provided the data on the political rights of each country. The information about the legal system came from the WGI (Worldwide Governance Indicators) website, and we extracted the economic data from the World Bank. The financial, legal and CG data are from 2016. Therefore, this article used cross-sectional data of the year 2016, with the exception of culture, due to its slow change throughout the years. The cultural aspect will be based on data from Hofstede Insights! We obtained the firms' data for the control variables and for the calculation of the earnings management variable on the Economatica database. We extracted the legal variables from Freedom House and $^{\mathrm{ii}}$ Worldwide Governance Indicators ${ }^{\mathrm{iii}}$ and the variables that measure cultural dimensions were presented by Hofstede, in his website Hofstede Insights' .

We selected earnings management measurement of transparency - for this study among the mechanisms of CG due to its importance in the studies of Leuz et al. (2003), Fernandes and Ferreira (2007), Correia et al. (2011), Peixoto et al. (2014), Kolozsvari and Macedo (2016), which adopted similar variables.

\subsection{Selection of the study variables}

\subsubsection{Dependent variable}

We chose the dependent variable earnings management to represent CG. Table 1 describes its equation.

\section{Table 1}

Calculation of the Dependent Variable Earnings Management

\begin{tabular}{c|c|c}
\hline Variable & Measurement & Description \\
\hline EM1 & $E M 1=\frac{\sigma(\text { LDIRit })}{\sigma(\text { CFOit })}$ & $\begin{array}{c}\text { It measures the smoothing of reported operating } \\
\text { earnings using the cumulative values of each } \\
\text { company. }\end{array}$ \\
\hline EM2 & $E M 3=\frac{|A C C|}{|C F O|}$ & $\begin{array}{c}\text { It measures the smoothing and correlation } \\
\text { between accruals and operating cash flows. }\end{array}$ \\
\hline EM-M & Mean of the previous three variables & $\begin{array}{c}\text { It measures the variation of reported profits, that } \\
\text { is, the accrual magnitude (ACC). }\end{array}$ \\
\hline
\end{tabular}

Source: Adapted from Leuz et al. (2003) and Correia et al. (2011).

Where: PAIT $_{i t}=$ Profit after income tax of company $i$ at time $t$; $C F O_{i t}=$ Cash flow of the operations of company $i$ at time t; $\mathrm{ACC}=(\mathrm{AC}-\mathrm{i}$ at time $\mathrm{t} ; \mathrm{ACC}=(\triangle \mathrm{AC}-\Delta \mathrm{CASH})-(\Delta \mathrm{CL}-\Delta \mathrm{SD}-\Delta \mathrm{TP})-\mathrm{DEP} ; \Delta \mathrm{AC}=$ variation of total current assets; $\Delta \mathrm{CASH}=$ variation of available cash and short-term investments; $\Delta C L=$ variation of total current liabilities; $\Delta S D=$ variation of shortterm debt included in the current liabilities; $\triangle T P=$ variation income tax payable; DEP = depreciation and amortization expense. 
Table 2

Control Variables

\begin{tabular}{|c|c|c|c|}
\hline Variables & Source: & Author & $\begin{array}{l}\text { Expected } \\
\text { Ratio }\end{array}$ \\
\hline \multicolumn{4}{|c|}{ Legal Variables } \\
\hline Political Rights (PR): & $\begin{array}{l}\text { Freedom } \\
\text { House. }\end{array}$ & Stulz (2005); Griffin et al. (2017) & - \\
\hline Rule of Law (RL) & WGI. & $\begin{array}{l}\text { La Porta et al. (1998); Leuz et. al. (2003); Pevzner et al. } \\
\text { (2015) }\end{array}$ & + \\
\hline \multicolumn{4}{|l|}{ Firm-level Variables } \\
\hline Size (SIZE) & Economatica & $\begin{array}{c}\text { Griffin et al. (2017); Leuz et al. (2003); Volonté (2015); } \\
\text { Pevzner et al. (2015) }\end{array}$ & - \\
\hline Debt (DEB) & Economatica & Griffin et al. (2017); Volonté (2015) & + \\
\hline Sales Growth (SG) & Economatica & Griffin et al. (2017); Volonté (2015) & - \\
\hline ADR & Economatica & Leuz et al. (2003); Stulz (2005); Griffin et al. (2017) & + \\
\hline
\end{tabular}

Firm-Level Variables: (a) company size: calculated by the natural logarithm of total assets; (b) debt, which is the ratio of total liabilities to total assets; (c) sales growth, which is the ratio of the 2016 revenue to the 2015 revenue; and (d) the emission of ADRs, to verify if the companies of the sample issue shares at the North-American stock markets. This variable considers the argument that firms in countries with low level of investors protection tend to implement better governance practices, so they can trade stocks in the North-American exchanges (Stulz, 2005; Doidge et al., 2007; Correia et al., 2011).

\subsection{Econometric model of this study}

Griffin et al. (2017) inspired the proposed model; however, other authors contributed with some ideas, such as: (1) to use the dependent variable "earnings management" based on Leuz et al. (2003), Peixoto et al. (2014), Pevzner et al. (2015), Correia et al. (2017) and Nezlobin et al. (2018); (2) to test Hofstede's cultural dimensions based on Callen et al. (2011) and Desender et al. (2011); (3) to add legal variables as proposed by La Porta et al. (1998) and other authors, proving the originality of this investigation.

$$
\text { TRANSP }=\beta_{0}+\beta_{i} H D+\beta_{j} L V+\beta_{k} F V+\varepsilon
$$

Where: $\beta_{0}$ : interceptor; HD: Independent variables regarding Hofstede's cultural dimensions; LV: Legal control variables; FV: Firm-level control variables.

We adjusted and reviewed these econometric models considering two types of analysis: (a) a complete model with four cultural dimensions of
Hofstede; (b) four regression models, one for each variable of culture (power distance, individualism, uncertainty avoidance, and long term orientation).
TRANSP $=\beta_{0}+\beta_{i} H D+\beta_{k} F V+\beta_{l} L V+\beta_{x} A D R+\varepsilon$

TRANSP $=\beta_{0}+\beta_{i} P D+\beta_{k} F V+\beta_{l} L V+\beta_{x} A D R+\varepsilon$

TRANSP $=\beta_{0}+\beta_{i}$ IND $+\beta_{k} F V+\beta_{l} L V+\beta_{x} A D R+\varepsilon$
(Model 1)

(Model 2)

(Model 3)

(Model 4) 
TRANSP $=\beta_{0}+\beta_{i} L T O+\beta_{k} F V+\beta_{l} L V+\beta_{x} A D R+\varepsilon$

(Model 5)

Where: $\beta_{0}$ : interceptor; HD: it includes all the variables of Hofstede's cultural dimensions; PD: it includes Power Distance; IND: it considers Individualism; UA: it considers Uncertainty Avoidance; LTO: Long Term Orientation; LV: Legal control variables; FV: Firm-level control variables; ADR: it is a dummy variable that indicates if the companies of the sample issue shares at the North-American stock markets.

\section{Results}

\subsection{Descriptive Statistics}

Considering a firm level, Table 3 presents the descriptive analysis of financial data obtained through Economatica database. The dependent variable is Earnings Management (which is the simple average of income management variables, summarized in Table 1). The average for the Earnings Management in the sample of this study is 0.56 .

\section{Table 3}

Descriptive analysis of financial data, considering a firm level

\begin{tabular}{lccccc}
\hline \multicolumn{1}{c}{ Variable } & Obs & Mean & Std. Dev. & Min & Max \\
\hline EM-M & 3,687 & 0.56782 & 0.12866 & 0.02299 & 0.95813 \\
\hline ADRs* & 3,687 & 0.08869 & 0.284334 & 0 & 1 \\
\hline CompanySize & 3,682 & 13.48194 & 2.187519 & 6.160032 & 19.83477 \\
\hline Debt & 3,682 & 0.66555 & 1.719478 & -0.1659 & 74.35336 \\
\hline SalesGrowth & 3,687 & 0.406756 & 8.336214 & -2.21656 & 376.0118 \\
\hline
\end{tabular}

* Dummy variable; the value indicates its percentage.

Additionally, Table 3 indicates that only $8.87 \%$ of the firms issue ADRs, but this information has an influence of American companies, since none of the
American companies issues such certificate, as it is possible to see at Table 4.

\section{Table 4}

Descriptive analysis of financial data, considering a country level

\begin{tabular}{l|c|c|c|c|c|c}
\multicolumn{1}{c|}{ Country } & Obs & EM-M & CompSize & Debt & SalesGrowth & ADRs* \\
\hline Argentina & 63 & 0.61139 & 12.51954 & 0.711431 & 1.04982 & 0.253968 \\
\hline Brazil & 400 & 0.57548 & 13.1825 & 1.218154 & 0.0116393 & 0.055 \\
\hline Canada & 100 & 0.44308 & 14.20855 & 0.502487 & -0.0240425 & 0.8 \\
\hline Chile & 168 & 0.62296 & 12.84922 & 0.566937 & 0.0049338 & 0.077381 \\
\hline China & 72 & 0.58644 & 13.89844 & 0.469883 & 0.3522306 & 1 \\
\hline Colombia & 26 & 0.62487 & 13.89662 & 0.550491 & 0.1247171 & 0.076923 \\
\hline France & 10 & 0.40751 & 13.98462 & 0.508167 & 0.0800779 & 1 \\
\hline Greece & 13 & 0.43770 & 13.17314 & 0.629251 & 0.0461196 & 1 \\
\hline Mexico & 111 & 0.63296 & 13.98531 & 0.578097 & 0.1549335 & 0.216216 \\
\hline Peru & 105 & 0.61729 & 12.40106 & 0.449583 & 0.0885122 & 0.038095 \\
\hline Taiwan & 15 & 0.54795 & 15.52743 & 0.425824 & 0.0459544 & 1 \\
\hline The Netherlands & 20 & 0.57338 & 15.4933 & 0.634691 & 0.0152562 & 1 \\
\hline The United Kingdom & 36 & 0.49638 & 15.32438 & 0.639613 & 0.2083378 & 1 \\
\hline The United States of America & 2548 & 0.56299 & 13.51837 & 0.612698 & 0.5359103 & 0 \\
\hline
\end{tabular}

* Dummy variable; the value indicates its percentage. 
Table 4 presents, by country, the descriptive statistics of financial data. Regarding the proxy for governance (EM), the countries with the highest values are México $(0.63)$ and Colombia $(0.62)$, while the countries with the lowest indexes are France $(0.40)$ and Greece (0.43). Considering the observations of Latin America, the country with more ADRs is Argentina $(0.254)$, and Peru $(0.038)$ is the country with less ADRs in the sample considered in this research.
Table 5 presents Hofstede's cultural dimensions, and the methodology used by Hofstede to calculate these values is based on a relative comparison among all countries studied. The country with the highest value for each dimension is 100 and the lowest is 1. Mexico and China have the highest levels of Power Distance, while the UK and the USA showed the highest values for Individualism, which indicates a strong consciousness and independency of their citizens.

Table 5

Cultural Dimensions according Hofstede

\begin{tabular}{l|c|c|c|c}
\hline \multicolumn{1}{c|}{ Country } & PD & Indiv & UncAvo & LongTerm \\
\hline Argentina & 49 & 46 & 86 & 20 \\
\hline Brazil & 69 & 38 & 76 & 44 \\
\hline Canada & 39 & 80 & 48 & 36 \\
\hline Chile & 63 & 23 & 86 & 31 \\
\hline China & 80 & 20 & 30 & 87 \\
\hline Colombia & 67 & 13 & 80 & 13 \\
\hline France & 68 & 71 & 86 & 63 \\
\hline Greece & 60 & 35 & 100 & 45 \\
\hline Mexico & 81 & 30 & 82 & 24 \\
\hline Peru & 64 & 16 & 87 & 25 \\
\hline Taiwan & 58 & 17 & 69 & 93 \\
\hline The Netherlands & 38 & 80 & 53 & 67 \\
\hline The United Kingdom & 35 & 89 & 35 & 51 \\
\hline The United States of America & 40 & 91 & 46 & 26 \\
\hline
\end{tabular}

Notes: PD = Power distance; Indiv = Individualism; UncAvo = Uncertainty Avoidance; LongTerm = Long-term Orientation.

In the dimension Uncertainty Avoidance, which considers the concerns of the society of a given country in knowing the future and guarantee a stable structure of life, Greece is the leader, with an absolute value of 100 , while China registered 30 . On the other hand, for Long-Term Orientation, Colombia, Argentina and Mexico show the lowest values, and China, together with Taiwan, present the highest values.

Pearson correlation was implemented to analyse the possible correlations between the cultural dimensions and EM. Results were not reported, but can be submitted if required. Many culture dimensions showed high correlations with EM. After this, we also found high values for correlation among the groups of cultural dimensions. The presence of significant relationship between the independent variables in a multivariate regression model could present concerns with multicollinearity. Therefore, we tested a complete model with the four variables related to culture and four models, one for each dimension of culture .

\subsection{Multivariate Regression Analysis}

We adjusted the quantitative models presented in section 3 and ran the multivariate regression analysis in order to analyze the relationships among culture, legal system, and EM. Table 8 presents the results for the five models. 
Table 6

Results for the Multivariate Regression Analysis

\begin{tabular}{l|c|c|c|c|c}
\hline \multicolumn{1}{c|}{ Variable } & UnAvoid (1) & Indiv (2) & LongTerm (3) & PowDist (4) & 4 Dimensions (5) \\
\hline Company Size & $0.0078^{* * *}$ & $0.0078^{* * *}$ & $0.0074^{* * *}$ & $0.0074^{* * *}$ & $0.0078^{* * *}$ \\
\hline Debt & -0.0018 & -0.0018 & -0.0017 & -0.0019 & -0.0014 \\
\hline Sales Growth & -0.0004 & -0.0004 & -0.0004 & -0.0004 & -0.0004 \\
\hline ADRs & $-0.0831^{* * *}$ & $-0.0846^{* * *}$ & $-0.0664^{* * *}$ & $-0.0755^{* * *}$ & $-0.0711^{* * *}$ \\
\hline Rule of Law & $0.0005^{*}$ & 0.0001 & $-0.0007^{* * *}$ & -0.0003 & 0.0005 \\
\hline Political Rights & $0.0246^{* * *}$ & $0.0093^{* *}$ & $0.0129 * * *$ & 0.006 & $0.0193^{*}$ \\
\hline Uncertainty Avoidance & $0.0013^{* * *}$ & & & & 0.0000 \\
\hline Individualism & & $-0.0008^{* * *}$ & & & $-0.0012^{* * *}$ \\
\hline Long Term Orientation & & & $-0.0006^{* *}$ & & $-0.0012^{* * *}$ \\
\hline Power Distance & & & & $0.0009 * * *$ & -0.0005 \\
\hline Constant & $0.3215^{* * *}$ & $0.5073^{* * *}$ & $0.5352^{* * *}$ & $0.4490^{* * *}$ & $0.5543^{* * *}$ \\
\hline $\mathrm{N}$ & 3651 & 3651 & 3651 & 3651 & 3651 \\
\hline r2 & 0.0543 & 0.0549 & 0.0495 & 0.0502 & 0.0595 \\
\hline F & 25.9753 & 27.2479 & 24.0542 & 23.7114 & 22.2647 \\
\hline Rmse & 0.1252 & 0.1252 & 0.1256 & 0.1255 & 0.1249
\end{tabular}

Notes: in each regression analysis, we have employed the robust residuals of White; Significance Level: ${ }^{*} 0.10 ; * * 0.05$; $* * * 0.01$.

Regarding the political rights, we found a positive relationship between this variable and earnings management (EM), which is coherent with Stulz (2005), who found that companies in environments with weak political rights should adopt a better level of corporate governance as a compensation. This suggests that countries with less political rights tend to present lower levels of earnings management, seeking a kind of compensation for potential investors.

The variable Rule of Law presented a negative relationship with EM in Model 3, and this variable represents a ranking of the countries considering their efficacy in applying laws and rules. Therefore, a better position in the ranking of the countries in the sample (regarding Rule of Law) is associated with lower levels of Earnings Management, which is in line with the literature (Leuz et al., 2003; Pevzner et al., 2015). In other words, the results suggest that firms from countries with higher levels of Rule of Law tend to provide greater transparency for investors, considering the results of Model 3. It is important to note that the negative relationship between Rule of Law and EM was not observed in the other models.

Considering all the five regression models, there is a positive and significant relationship between firm's size and EM, indicating that large firms tend to present higher levels of earnings management, which can affect their transparency, and this result is in line with Volonté (2015) and Griffin et al. (2017). Moreover, another result obtained in Table 6, in all regression models, is that companies that issue ADRs at the North-American stock markets tend to have a lower level of earnings management. Such results were expected and they are in line with the studies of Doidge et al. (2005), Lopes and Walker (2008) and Correia et al. (2011). The variables Debt and Sales Growth did not show a significant relationship with EM in any of the quantitative models tested.

Regarding the study hypotheses, Model 4, that considers Power Distance (PD) as the independent variable for cultural dimension, showed a positive and significant relationship between PD and EM, which corroborates the first hypothesis ( $\mathrm{H} 1$ : Earnings management is positively related to the degree of Power Distance). This finding is in line with the studies of Callen et al. (2011) and Paredes and Wheatley (2017). In Model 5, that simultaneously considers the four dimensions of culture, the relationship between PD and EM was not significant. Based on the results of Table 6, specifically in Models 2 and 5, the second hypothesis of the study was confirmed ( $\mathrm{H} 2$ : Earnings management is negatively related to the degree of individualism), since the relationship between individualism and EM was negative and significant. This finding is in line with the studies of Callen et al. 
(2011), Desender et al. (2011), and Paredes and Wheatley (2017). However, this result contradicts the studies of Guan et al. (2005) and Han et al. (2010), that found a positive relationship between individualism and EM.

Model 1 of Table 6 shows a positive relationship between uncertainty avoidance and EM, which is in line with the third hypothesis of this study $(\mathrm{H} 3$ : Earnings management is positively related to the degree of uncertainty avoidance). This result corroborates the study of Callen et al. (2011), but it contradicts the studies of Guan et al. (2005), Han et al. (2010), and Astami et al. (2017). The Models 3 and 5 of Table 6 show a negative association between long term orientation and EM, which corroborates the fourth hypothesis (H4: Earnings management is negatively related to the degree of long term orientation). The result for long term orientation corroborates with the studies of Callen et al. (2011) and Guan et al. (2005). Therefore, all the hypotheses proposed in this study were corroborated at least in one of the quantitative models, and the observed signs for the relationships between the cultural dimensions of Hofstede and EM practices were in line with the expected directions presented in the descriptions of the hypotheses. Based on the global analysis of the five models, the results indicate that there is an important effect of the cultural dimensions on earnings management of firms located in the 14 countries of the sample. It is also possible to conclude that the legal variables were important in this analysis, which corroborates with the studies of La Porta et al. (1998), Leuz et al. (2003), Pevzner et al. (2015) and Stulz (2005). Finally, the variables in a firm level, especially the size of the companies and companies that issue ADRs, presented a relevant effect on the quantitative analysis.

\section{Discussion}

The recent economic and financial crises have led to a debate about the quality of earnings reported by firms. These crises also have raised the question on how to improve the quality of financial reports and the economic stability among countries. This study contributes to this debate, showing that the policies to reduce the EM do not involve only objective issues, but depend strongly on the cultural context of each country.

Among other results, we observed that in countries that individuals accept more strongly an unequal distribution of power in society (Power Distance) there is also a higher level of earnings management. We also noted that in more individualistic societies there is less incidence of earnings management practices. In countries that suffer more with the feeling of discomfort or insecurity with respect to risks (uncertainty avoidance) there is more earnings management. It was observed that in countries where individuals are oriented towards the future, towards economies and persistence (long term orientation), a lower level of earnings management occurs. These results proved to be quite in line with the literature on this subject (Astami et al., 2017; Callen et al., 2011; Desender et al., 2011). Our results point to an important link between informal institutions and the quality of financial information offered to economic agents in each country.

These results indicate that since culture has a significant impact on managers' practices, after controlling for legal variables and specific characteristics of firms, corporate governance configurations that take culture into account could succeed.

\section{Final Considerations}

The purpose of this study was to investigate if the culture of countries influences the practices of EM of their organizations. This study broke new ground by selecting proxies for governance and cultural dimensions and by adopting a cross-section multivariate regression for a sample of companies in the stock markets of the United States, Mexico, Brazil, Chile, Peru, and Colombia.

Regarding the methodology, we used the perspective of Leuz et al. (2003) for measuring EM and the perspective of Hofstede for measuring the cultural dimensions. Most articles (Callen et al., 2011; Desender et al., 2011; Doupnik, 2008) selected four cultural dimensions as the most important to relate with EM. Such dimensions were: power distance, individualism, uncertainty avoidance and long term orientation. After selecting the variables, we used regression models based on the literature to associate culture with EM.

We noted that culture plays a strong role in the development of CG practices, in particular regarding firms' EM, which confirms all the main hypothesis of this study. We can infer that certain characteristics of society are related to the practices of EM by 
managers, showing that the cultural environment of countries has a significant influence on financial and accounting decision-making of the organizations. Therefore, we hope we have contributed to elucidate the role of culture, legal relationships, and organizational development in companies and countries, highlighting the importance of the culture of a given country to understand the reason of its rules, legal system, and reasons that change CG in

\section{References}

Astami, E. W., Rusmin, R., Hartadi, B. \& Evans J. (2017). The role of audit quality and culture influence on earnings management in companies with excessive free cash flow: Evidence from the Asia-Pacific region. International Journal of Accounting \& Information Management, 25(1), 21-42. https://doi.org/10.1108/IJAIM-05-2016-0059

Bao, S.R. \& Lewellyn, K.B. (2017). Ownership structure and earnings management in emerging markets-An institutionalized agency perspective. International Business Review, 26(5), 828-838. https://doi.org/10.1016/j.ibusrev.2017.02.002

Barros, C. M. E., Soares, R., \& Lima, G. (2013). A relação entre governança corporativa e gerenciamento de resultados em empresas brasileiras. Revista de Contabilidade e Organizações, 7(19), 27-39. https://doi.org/10.11606/rco.v7i19.55509

Black, B., de Carvalho, A., Khanna, V., Kim, W. \& Yurtoglu, B. (2014). Methods for multicountry studies of corporate governance: Evidence from the BRIKT countries. Journal of Econometrics, 183(2), 230-240. https://doi.org/10.1016/j.jeconom.2014.05.013

Callen, J. L., Morel, M. \& Richardson, G. (2011). Do culture and religion mitigate earnings management? Evidence from a cross-country analysis. International Journal of Disclosure and Governance, 8(2), 103-121. https://doi.org/10.1057/jdg.2010.31

Correia, L., Amaral, H. \& Louvet, P. (2011). Um índice de avaliação da qualidade da GC no Brasil. Revista de Contabilidade e Finanças. 22(55), 45-63. https://doi.org/10.1590/s1519-70772011000100004

Correia, L., Amaral, H. \& Louvet, P. (2017). Governança corporativa e earnings management em empresas negociadas na BM\&FBOVESPA. Contabilidade $\begin{array}{lll}V i s t a & \text { R }\end{array}$ 28(2), 1-29. https://doi.org/10.11606/rco.v8i21.63219 companies. As a result, this study gives some hints on how to compare the differences between companies from several countries.

For future research, we suggest to explore other cultural dimension, such as the Globe Project, which studies cultural aspects, leadership, and organizational practices around the world, with access to several companies, managers, and CEOs.

Desender, K. A., Castro, C. E. \& De León, S. A. E. (2011). Earnings management and cultural values. American Journal of Economics and Sociology, 70(3), 639-670. https://doi.org/10.1111/j.1536-

\subsubsection{6.x}

Doidge, C., Andrewkarolyi, G. \& Stulz, R. (2007). Why do countries matter so much for corporate governance?. Journal of Financial Economics, 86(1), 139. https://doi.org/10.1016/i.jfineco.2006.09.002

Doidge, C., Karolyi, G., Lins, K., Miller, D. \& Stulz, R. (2005). Private benefits of control, ownership, and the cross-listing decision. ECGI - Finance Working Paper, 77. https://doi.org/10.2139/ssrn.668424

Doupnik, T.S. (2008). Influence of culture on earnings management: A note. Abacus, 44, 317-340. https://doi.org/10.1111/j.1467-6281.2008.00265.x

Fernandes, N. \& Ferreira, M. (2007). The evolution of earnings management and firm valuation: A crosscountry analysis. SSRN Electronic Journal. https://doi.org/10.2139/ssrn.965636

Ferreira, M. Serra, F. \& Pinto, C. (2014). Culture and Hofstede (1980) in international business studies: a bibliometric study in top management journals. REGERevista de Gestão, 21(3), 379-399.

Griffin, D., Guedhami, O., Kwok, C., Li, K. \& Shao, L. (2014). National Culture, Corporate Governance Practices, and Firm Performance. SSRN Electronic Journal. https://doi.org/10.2139/ssrn.2400078

Griffin, D., Guedhami, O., Kwok, C., Li, K. \& Shao, L. (2017). National culture: The missing country-level determinant of corporate governance. Journal of International Business Studies, 48(6), 740-762. https://doi.org/10.1057/s41267-017-0069-9 
Guan, L., Pourjalali, H., Sengupta, P. \& Teruya, J. (2005). Effect of cultural environment on earnings manipulation: A five Asia-Pacific country analysis. Multinational Business Review, 13(2), 23-41. https://doi.org/10.1108/1525383×200500007

Han, S., Kang, T., Salter, S. \& Yoo, Y. K. (2010). A cross-country study on the effects of national culture on earnings management. Journal of International Business Studies, 41(1), 123-141. https://doi.org/10.1057/jibs.2008.78

Healy P. M., \& Wahlen, J. M. A. (1999). Review of the earnings management literature and its implications for standard setting. Accounting Horizons, 13(4), 365-383. https://doi.org/10.2308/acch.1999.13.4.365

Hillier, D., Pindado, J., Queiroz, V. \& Torre, C. (2010). The impact of country-level corporate governance on research and development. Journal of International $\begin{array}{lll}\text { Business } \quad \text { 4tudies, } & \text { 76-98. }\end{array}$ https://doi.org/10.1057/jibs.2010.46

Hofstede, G. (1980). Culture's consequences: International differences in work-related values. Sage Publications.

Hofstede, G. (2001). Culture's consequences: Comparing values, behaviors, institutions, and organizations across nations (2th ed.). Sage Publications.

Holanda, A. P. (2012). Gerenciamento de resultados e estrutura de propriedade nas companhias de capital aberto no Brasil (Master dissertation). Retrieved from http://www.repositorio.ufc.br/handle/riufc/15074

IBGC, Instituto Brasileiro de GC (2015). Código das melhores práticas de governança corporativa. Instituto brasileiro de GC. (5th ed). https://www.ibgc.org.br/userfiles/files/Publicacoes/Pu blicacao-IBGCCodigo-CodigodasMelhoresPraticasdeGC5aEdicao.pdf

Jensen, M. \& Meckling, W. (1976). Theory of the firm: managerial behavior, agency costs and ownership structure. Journal of Financial Economics, 3(4), 305-360. https://doi.org/10.1016/0304-405x(76)90026-x

Khlif, H. (2016). Hofstede's cultural dimensions in accounting research: a review. Meditari Accountancy Research, 24(4), 545-573. https://doi.org/10.1108/MEDAR-02-2016-0041
Kirkman, B. L., Lowe, K. B. \& Gibson, C. B. (2006). A quarter century of culture's consequences: A review of empirical research incorporating Hofstede's cultural values framework. Journal of International Business Studies, 37(3), 285-320. https://doi.org/10.1057/palgrave.jibs.8400202

Klapper, L. \& Love, I. (2004). Corporate governance, investor protection, and performance in emerging markets. Journal of Corporate Finance, 10(5), 703-728. https://doi.org/10.1016/s0929-1199(03)00046-4

Kolozsvari, A. \& Macedo, M. (2016). Análise da influência da presença da suavização de resultados sobre a persistência dos lucros no mercado brasileiro. Revista Contabilidade \& Finanças, 27(72), 306-319. https://doi.org/10.1590/1808-057×201602610

Kumar, P. \& Zattoni, A. (2013). How much do country-level or firm-level variables matter in corporate governance studies?. Corporate Governance: An International Review, 21(3), 199-200. https://doi.org/10.1111/corg.12025

La Porta, R. Lopez-de-Silanes, F. Shleifer, A. \& Vishny, R. (1998). Law and finance. Journal of political economy, 106(6), 1113-1155. https://doi.org/10.1086/250042

Leuz, C., Nanda, D. \& Wysocki, P. (2003). Earnings management and investor protection: an international comparison. Journal of Financial Economics, 69(3), 505527. https://doi.org/10.1016/s0304-405x(03)00121-1

Licht, A., Goldschmidt, C. \& Schwartz, S. (2005). Culture, law, and corporate governance. International Review of Law and Economics, 25(2), 229-255. https://doi.org/10.1016/j.irle.2005.06.005

Lopes, A. \& Walker, M. (2008). Firm-Level Incentives and the Informativeness of Accounting Reports: An experiment in Brazil. SSRN Electronic Journal. https://doi.org/10.2139/ssrn.1095781

Martinez, A. L. (2013). Gerenciamento de resultados no Brasil: Um survey da literatura. Brazilian Business Review. 10(4), 1-31. http://dx.doi.org/10.15728/bbr.2013.10.4.1

Minkov, M. (2017). A revision of Hofstede's model of national culture: old evidence and new data from 56 countries, Cross Cultural \& Strategic Management, 1(1), 2-33. https://doi.org/10.1108/CCSM-03-2017-0033 
Nabar, S., \& Boonlert-u-thai, K.K. (2007). Earnings management, investor protection and national culture. Journal of International Accounting Research, 6(2), 3554. https://doi.org/10.2308/jiar.2007.6.2.35

Nezlobin, A., Sloan, R. \& Zha Giedt, J. (2018). Measuring accruals quality: A theoretical and empirical evaluation. SSRN Electronic Journal. https://doi.org/10.2139/ssrn.3301083

Paredes, A. A. P. \& Wheatley C. (2017). The influence of culture on real earnings management. International Journal of Emerging Markets, 12(1), 38-57. https://doi.org/10.1108/ijoem-12-2014-0218

Peixoto, F. M., Amaral, H. F. \& Correia L. F. (2014). Corporate governance, risk and capital cost: An analysis during crises in the first decade of the 21st century. Gestão \& Regionalidade, 30(90), 67-88.

Pevzner, M., Xie, F. \& Xin, X. (2015). When firms talk, do investors listen? The role of trust in stock market reactions to corporate earnings announcements. Journal of Financial Economics, 117(1), 190-223. https://doi.org/10.1016/j.jfineco.2013.08.004

Schipper, K. (1989). Commentary on Earnings Management. Accounting Horizons, 3(4), 91-102.

Soares, A. M., Farhangmehr, M. \& Shoham, A. (2007). Hofstede's dimensions of culture in international marketing studies. Journal of Business
Research,

60(4),

277-284.

https://doi.org/10.1016/j.jbusres.2006.10.018

Stahl, G. K., Miska ,C., Lee, H. \& De Luque, M. S., (2017). The upside of cultural differences towards a more balanced treatment of culture in cross-cultural management research. Cross Cultural \& Strategic Management, 24(1), 2-12. https://doi.org/10.1108/ccsm-11-2016-0191

Stulz, R. (2005). The limits of financial globalization, The Journal of Finance, 60(4), 1595-1638. https://doi.org/10.1111/j.1540-6261.2005.00775.x

Torres, D., Bruni, A. L., Rivera-Castro, M. A., \& Martinez, A. L. (2010). Ownership and control structures, corporate governance and income smoothing in Brazil. Revista Contemporânea de Contabilidade, 1(1), 11-34. http://dx.doi.org/10.2139/ssrn.1651991

Volonté, C. (2014). Culture and corporate governance: The influence of language and religion in Switzerland. Management International Review, 55(1), 77-118. https://doi.org/10.1007/s11575-014-0216-5

Zhang, X., Liang, X. \& Sun, H. (2013). Individualismcollectivism, private benefits of control, and earnings management: A cross-culture comparison. Journal of business ethics, 114 (4), 655-664. https://doi.org/10.1007/s10551-013-1711-5

\section{About Authors}

Pedro Paulo Melo Arantes - Universidade Federal de Uberlândia - UFU, Minas Gerais (Brasil). Email: pedropauloadm@yahoo.com.br Orcid id: https://orcid.org/0000-0003-2421-8373

Fernanda Maciel Peixoto - Universidade Federal de Uberlândia - UFU, Minas Gerais, (Brasil). Email: fmacielpeixoto@gmail.com Orcid id: https://orcid.org/0000-0002-0969-7567

Luciana Carvalho - Universidade Federal de Uberlândia - UFU, Uberlânica, Minas Gerais (Brasil). Email: lucarvalho@ufu.br Orcid id: https://orcid.org/0000-0001-9645-8718

Fernanda Francielle de Oliveira Malaquias - Universidade Federal de Uberlândia - UFU, Minas Gerais, (Brasil). Email: fernandafrancielle@ufu.br Orcid id: https://orcid.org/0000-0001-7997-530X 


\section{DETERMINANTES CULTURAIS DA GOVERNANÇA CORPORATIVA: UM ESTUDO MULTI-PAÍSES}

Pedro Paulo Melo Arantes, Fernanda Maciel Peixoto, Luciana Carvalho, Fernanda Francielle de Oliveira Malaquias Universidade Federal de Uberlândia - UFU, Uberlânica, MG (Brasil)

\section{DETALHES DO ARTIGO}

\section{Histórico do Artigo:}

Recebido: 5 de novembro de 2019

Aceito: 03 de março de 2020

Disponível online: 01 de maio de 2020

\section{Sistema de revisão "Double blind review"}

Editor Científico

Ilan Avrichir

\section{Palavras-chave:}

Governança corporativa Gerenciamento de Resultados Cultura

\section{RESUMO}

Objetivo: buscou-se investigar se a cultura dos países influencia as práticas de gerenciamento de resultados. O gerenciamento de resultados (GR) foi escolhido como um mecanismo de Governança Corporativa.

Método: foram escolhidas as proxies de GR de Leuz et al. (2003). Adotou-se as dimensões culturais de Hofstede. A amostra foi composta por empresas listadas, em 2016, nas bolsas de valores do Brasil, Argentina, México, Chile, Colômbia, Peru e Estados Unidos. Este trabalho envolveu análise de regressão para associar as dimensões de cultura com as práticas de EM das firmas.

Resultados: os resultados apontaram uma relação positiva entre GR e power distance e entre GR e aversão a incerteza. Por outro lado, os resultados mostraram uma relação negativa entre $G R$ e individualismo e entre $G R$ e orientação a longo prazo. Em geral, nossos resultados sugerem que a cultura influencia no gerenciamento de resultados das firmas.

Originalidade: A literatura de finanças tem tido dificuldade em avaliar quais variáveis podem afetar o desenvolvimento da GC nas empresas e suas peculiaridades em cada país. Também é difícil encontrar variáveis no nível país que sejam comuns a todos os países. Este artigo abre novos caminhos, desenvolvendo indicadores de cultura dos países e agregando variáveis legais e de nível de firma a esses indicadores para avançar no entendimento da GC nas firmas e países.

Contribuições teóricas: a análise da cultura em nível multi-país é importante para aprofundar a compreensão dos aspectos comuns e das particularidades dos países que podem afetar o relacionamento entre governança corporativa e desempenho ao redor do mundo. 


\section{DETERMINANTES CULTURALES DE LA GOVERNANZA CORPORATIVA: UN ESTUDIO MULTIPAÍS}

Pedro Paulo Melo Arantes, Fernanda Maciel Peixoto, Luciana Carvalho, Fernanda Francielle de Oliveira Malaquias Universidade Federal de Uberlândia - UFU, Uberlânica, MG (Brasil)

\begin{tabular}{l}
\hline HISTORIA DEL ARTÍCULO \\
\hline Historia del Artículo: \\
Recibido: 5 de noviembre de 2019 \\
Aceptado: 3 de marcha de 2020 \\
Disponible en línea: 01 de Mayo 2020 \\
Double Blind Review System \\
Editor Científico \\
llan Avrichir
\end{tabular}

\section{Palabras-clave:}

Gobierno corporativo Earnings Management Cultura

\begin{abstract}
RESUMEN
Objetivo: El objetivo de este artículo es verificar los efectos de los estímulos desencadenantes en la internacionalización y si la ambidestreza y los modelos mentales (MM) aumentan la predisposición a las exportaciones, así como si el país de origen causa diferencias en términos de cognición.

Método: La recopilación de datos consistió en aplicar un cuestionario a una muestra de 285 estudiantes de programas de Administración en Brasil y España. ANOVA Welsh se usó para verificar la heterogeneidad de las variaciones, las pruebas de Kolmogorov-Smirnov y Shapiro-Wilk se usaron para evaluar la normalidad, y las pruebas no paramétricas de Kruskal-Wallis se usaron para verificar los resultados de las pruebas anteriores.

Resultados principales: Los resultados mostraron que el MM estratégico facilita la internacionalización. En la muestra estudiada, fue posible verificar que los brasileños muestran una tendencia operativa y un estilo de vida improvisado, lo que denota una menor posibilidad de participar en la internacionalización.

Relevancia: Este estudio es relevante para proponer la creación de índices para obtener datos sobre el MM y la ambidestreza con respecto a la identificación de los factores de motivación personal que influyen en la inserción del emprendedor en los mercados internacionales.

Contribuciones teóricas / metodológicas: Propuesta de una fórmula para estandarizar y reescalar el valor de los instrumentos, ya que las diferencias entre escalas pueden contribuir a la inclusión de una dimensión oculta del proceso de internacionalización: el análisis de la cognición.
\end{abstract}

\section{Cite it like this:}

Arantes, P., Peixoto, F., Carvalho, L., \& Malaquias, F. (2020). Cultural Determinants of Corporate Governance: A Multi-Country Study. Internext, 15(2), 56-71. doi: http://dx.doi.org/10.18568/internext.v15i2.580 